\title{
THE HARM PRINCIPLE AND THE GREATEST HAPPINESS PRINCIPLE: THE MISSING LINK
}

\author{
Cinara Nahra* \\ cinaranahra@hotmail.com
}

RESUMO Neste artigo, apresento uma solução possível para o clássico problema da aparente incompatibilidade entre o Princípio da Maior Felicidade de John Stuart Mill e seu Princípio da Liberdade, argumentando que na esfera "concernente aos outros" os julgamentos de experiência e o conhecimento acumulado através da história têm força moral e legal, enquanto na esfera "autoconcernente" os julgamentos dos experientes têm apenas valor prudencial, e a razão para isto é a ideia que cada um de nós é um juiz, melhor do que qualquer outra pessoa, para decidir o que nos causa dor e que tipo de prazer preferimos (o assim chamado argumento epistemológico). Considerando que o Princípio da Maior Felicidade não é nada mais do que o agregado da felicidade de cada pessoa, levando em consideração o argumento epistemológico concluiríamos que, deixando as pessoas livres até mesmo para causar dano a elas mesmas, ainda estaríamos maximizando a felicidade, e então ambos os princípios (O Princípio da Maior Felicidade e o Princípio da Liberdade) poderiam ser compativeis.

Palavras-chave John Stuart Mill, Princípio da Maior Felicidade, Princípio da Liberdade.

ABSTRACT In this article I present a possible solution for the classic problem of the apparent incompatibility between Mill's Greatest Happiness

* Professora do Departamento de Filosofia da UFRN. Artigo recebido em 14/11/2012 e aprovado em 18/08/2013. 
Principle and his Principle of Liberty arguing that in the other-regarding sphere the judgments of experience and knowledge accumulated through history have moral and legal force, whilst in the self-regarding sphere the judgments of the experienced people only have prudential value and the reason for this is the idea according to which each of us is a better judge than anyone else to decide what causes us pain and which kind of pleasure we prefer (the so-called epistemological argument). Considering that the Greatest Happiness Principle is nothing but the aggregate of each person's happiness, given the epistemological claim we conclude that, by leaving people free even to cause harm to themselves, we still would be maximizing happiness, so both principles (the Greatest Happiness Principle and the Principle of Liberty) could be compatible.

Keywords John Stuart Mill, Greatest Happiness Principle, Principle of Liberty.

\section{The Greatest Happiness Principle and the Harm Principle}

In Mill's view morality is founded on utility, and utility is synonymous with the Greatest Happiness Principle: ${ }^{1}$

The creed which accepts as the foundation of morals Utility, or the Greatest Happiness Principle, holds that actions are right in proportion as they tend to promote happiness, wrong as they tend to produce the reverse of happiness. By happiness is intended pleasure, and the absence of pain; by unhappiness, pain, and the privation of pleasure.

Mill's Greatest Happiness Principle (Principle of Utility) establishes that happiness is the ultimate criterion to establish what is moral and what is not, i.e., the ideal moral society is the one where everybody is happy and everybody is free of pain. Such an idea, however, could be problematic, since it is a fact of life that the happiness of individuals sometimes conflicts. For instance, if individual A thinks that money is a fundamental means of increasing his/her happiness and decreasing his/her suffering and decides to steal from B he/she will, then, be probably happier after he/she has successfully concluded the robbery. The problem is that B will be probably less happy and suffering more after being robbed and, thus, if the criterion of utility were based only on the happiness of each individual, it would be completely useless to guide people's 
actions, especially the ones where there is conflict of interests. Mill was well aware of this, which is why he makes it clear that the utilitarian standard is not the agent's own happiness, but the greatest amount of happiness altogether. ${ }^{2}$

But what does "the greatest amount of happiness altogether" mean? It seems that Mill provides an answer to this question when he attempts to prove the principle of utility in chapter 4 of "Utilitarianism". He says: ${ }^{3}$

No reason can be given why the general happiness is desirable, except that each person, so far as he believes it to be attainable, desires his own happiness. This, however, being a fact, we have not only all the proof which the case admits of, but all which it is possible to require, that happiness is a good; that each person's happiness is a good to that person, and the general happiness, therefore, a good to the aggregate of all persons.

When Mill says, then, that the criterion of morality is the greatest amount of happiness altogether, he is not saying that there is a metaphysical concept of happiness that is reachable regardless the happiness of each individual. On the contrary, he is saying that the greatest amount of happiness altogether is nothing but the sum of the happiness of each one of us. In other words, it means that the more each one of us is happy and free of pain, the bigger amount of total happiness will be obtained and, conversely, the more each one of us suffers, the more the greatest amount of happiness is diminished.

However, two problems still remain. The first one is that apparently we have again to start from scratch, because since Mill establishes that the happiness of each person really matters, how is it possible to decide in situations of conflict of happiness, such as the robbery case described earlier? What would increase the sum of happiness: a) A stealing from B or b) A not stealing from B? The Utility Principle alone could not give such an answer, since in this hypothetical case (and supposing that only A and B will know about the robbery) the total amount of happiness will be the same in both cases. It is exactly at this point, and in order to decide about questions like this, that additional principles such as the Harm Principle can help. If we apply the Harm Principle, an answer to the question about which action is right is immediately provided, since this principle demands that we should have liberty of tastes and pursuits without impediment from our fellow-creatures, so long as what we do does not harm them. ${ }^{4}$ 
If that is the case, the application of the Harm Principle would rule out action a) and classify it as wrong, since it breaches the Harm Principle, because $\mathrm{A}$ is clearly harming $\mathrm{B}$ in our example. The use of other principles in order to complement the Utility Principle is clearly admitted by Mill. According to $\operatorname{him}:^{5}$

It is a strange notion that the acknowledgement of a first principle is inconsistent with the admission of secondary ones. To inform a traveller respecting the place of his ultimate destination is not to forbid the use of landmarks and direction- posts on the way. The proposition that happiness is the end and aim of morality, does not mean that no road ought to be laid down to that goal, or that persons going thither should not be advised to take one direction rather than another... Whatever we adopt as the fundamental principle of morality, we require subordinate principles to apply it by: the impossibility of doing without them, being common to all systems, can afford no argument against any one in particular: but gravely to argue as if no such secondary principles could be had, and as if mankind had remained till now, and always must remain, without drawing any general conclusions from the experience of human life, is as high a pitch, I think, as absurdity has ever reached in philosophical controversy.

It seems that in saying this, Mill was making room for the use of his Harm Principle as a way of showing people how to reach the Greatest Happiness, exactly like sign posts are used on roads. In fact, the minimization of suffering is perfectly compatible with people abstaining from causing harm to others and this is almost self-evident if we apply the so-called utilitarian generalization ${ }^{6}$ since if everybody stopped causing harm to others, it would produce less pain in the world. The minimization of pain can be easily conciliated with the Harm Principle prohibiting people from causing harm to others, and minimization of pain is precisely one of the demands of the Greatest Happiness Principle. Thus, it seems that there is no contradiction a priori between the Greatest Happiness Principle and the Harm Principle; on the contrary, the second could complement the first, as a means to an end. Saying this does not imply that the Harm Principle is derived from the Greatest Happiness Principle, but it does imply that the Harm Principle can not only converge with the Greatest Happiness Principle, but can also help us to reach the main purpose of the Greatest Happiness Principle.

Notice, however, that the Harm Principle is far from being uncontroversial. Too much has already been said about what harm to others meant to Mill, but this certainly does not mean that: a) there is not a core of things that clearly cause harm to others and, b) people are not allowed to cause any kind of harm

6 On utilitarian generalization see Lyons (1965). 
to anyone. There are some types of "harm" that can be justified, for example, if two people A and B are disputing the same job, and A gets the job and B does not, it could be said in a broad sense that A harmed B, but this would not count properly as 'harm' as competition for a job is legitimate, lawful, and in line with Mill's economic and liberal views; if economic competition causes damage to people on occasion, it is still in the best interest of society. However, if A gets the job because he hijacked B on the day of the interview, impeding B to be present, this is clearly a harmful action. Mill does concede that some types of damage to others should be admitted to, in order to promote utility, but then it is doubtful that these could be properly called "harm" (harmful acts). ${ }^{7}$ The main proposal of Mill's Harm Principle is not to disallow any possible kind of damage to others, but instead to establish a criteria able to guide people on how they should and should not treat other people and to set boundaries on what should be rightly interfered with or not, by the people and the state, in other people lives, always bearing in mind that the moral ideal to be attained to is a world where people can be the happiest they can be, with the least amount of suffering. ${ }^{8}$

\section{Utility and Liberty: The Missing Link}

There is, nevertheless, a second problem, a possible contradiction between the two principles caused by Mill's requirement in the Harm Principle that the self-regarding sphere should not be violated, i.e., a ring of protection in the selfregarding sphere should be guaranteed for each individual, in the sense that in this sphere individuals should be totally free to make their own decisions and to experiment without being interfered with through social pressure and the law. The possible objection is straightforward, that is, if total liberty in the self-regarding sphere is a requirement of the Harm Principle, it does mean that people should be free even to harm themselves and if people do harm

7 Feinberg (1984) uses the expression wrongful harms to classify the kind of harms that Mill would not allow. A wrongful harm to Feinberg is one that violates a right.

8 My suggestion is that this criterion is fivefold a) In order for an action $X$ to be considered immoral and wrong, $X$ has to cause harm to others, in other words, harm to others is a necessary condition for $X$ to be considered immoral and wrong; b) A should have complete liberty to do X, since the only person directly affected by $X$ is him/herself or a B that, voluntarily and undeceived, consented to $X ; c)$ Even if the majority of people in any society think that $A$ doing $X$ is wrong, $X$ should not be interfered with (through law or social discrimination) unless $X$ causes harm to others; $d$ ) In order to establish whether or not $X$ causes harm to others, considerations about "distaste" and "dislike" have to be disregarded if the person that is distressed is not, directly and in the first instance, involved in the action or suffering the consequences of the action; e) Actions X otherwise non-harmful, if publicly done, are subject to further discussion in order to establish whether they can or cannot be interfered with, since being public the action cannot be considered selfregarding any more. 
themselves it would be a breach of the Greatest Happiness Principle that demands minimization of pain. Thus, apparently, in some cases a conflict between the demands of the two principles would be inevitable. One possible example would be the case of people that cause pain to themselves or even mutilate themselves without any apparent utility justifying it. Imagine, for example, that suddenly a group of people had decided to cut off their left little toes. It seems to be a typical example of a self-regarding action, since it would hardly affect someone apart from the perpetrators of the action. The Harm Principle would then allow the action, but what about the Greatest Happiness Principle? Apparently, since to cut off toes is painful (let us imagine it was done without anesthetics), the action would be painful for the agents and it would cause an increase of pain in the world. The action would then be considered wrong and ruled out by the Utility Principle. In this case, then, there would be a contradiction between the demands of the two principles, since the Harm Principle would permit the action and the Utility Principle would not. A further step would be saying that since the Greatest Happiness Principle is the ultimate end of morality it should be used in order to judge this action and the Harm Principle should be then disregarded, and this would, in a sense show that Mill's theory, be "schizophrenic", i.e., there is an "utilitarian" Mill and a "liberal" one, and the results that they reach in judging actions are in opposition; the utilitarian Mill would provide answers that contradict the liberal one.

That solution and the associated interpretation of Mill's philosophy are wrong, and the reason why they are wrong is because they fail to grasp the link between the Harm Principle and the Greatest Happiness Principle. In order fully to understand this link and its consequences in the analyses of selfharm, it is necessary to carefully analyse Mill's reasoning. After enunciating his Utility Principle, Mill immediately claims that 9 "to give a clear view of the moral standard set up by the theory, much more requires to be said; in particular what things it includes in the ideas of pain and pleasure; and to what extent this is left an open question". He then proceeds to his affirmation: ${ }^{10}$

If the sources of pleasure were precisely the same to human beings and to swine, the rule of life which is good enough for the one would be good enough for the other... Human beings have faculties more elevated than the animal appetites, and when once made conscious of them, do not regard anything as happiness which does not include their gratification... It is quite compatible with the principle of utility to recognize the fact that some kind of pleasures are more desirable and more valuable than others. 
What Mill wanted to say here and in the following paragraphs is well known. Human beings are able to have some higher pleasures (most of them intellectual pleasures, but not only) which animals are not, and these pleasures are more desirable and more valuable than others. ${ }^{11}$ In order to decide which pleasures are qualitatively more valuable, he establishes the following criterion: ${ }^{12}$ of two pleasures, if there be one to which all or almost all who have experience of both give a decided preference, irrespective of any feeling of moral obligation to prefer it, that is the most desirable pleasure.

What Mill seems to be saying here is that there is an objective criterion to judge what kinds of pleasure are preferable. This criterion is provided by experience, and this experience is only possible if humankind (considered as each of the individuals) is allowed to experiment in life and to learn from the experiences of others, the only way that each of us (and, then, humankind in general) can be acquainted with pleasures. Thus, the experience that Mill refers to ends up being the historical experience of humankind that gives us an objective criterion to decide between pleasures which one is preferable, and what, in general terms, leads to happiness (and suffering) or not. Mill enumerates great sources of physical and mental suffering in life, such as indigence, disease, and the unkindness, worthlessness or premature loss of objects of affection. ${ }^{13}$ What he seems to be saying is that humankind knows, through experience, that these things described earlier are sources of suffering, as well as that humankind has accumulated knowledge about which kinds of pleasure are more valuable. Thus, individual $\mathrm{C}$ that causes pain to someone alleging that he /she did not know which kind of pleasure the other would prefer, should be subject to moral and criminal condemnation. In order to illustrate this, let us suppose that $\mathrm{C}$ is HIV positive and intentionally had unsafe sex with his/her partner, who did not know that the partner was HIV positive. After infecting the partner, $\mathrm{C}$ alleges that the sexual pleasure that he/she caused to the partner was so intense that it would outweigh the damage caused by infecting the partner with the virus. At this point, we need to use Mill's criterion about competent judges. Humankind has learned that the pleasure of having good health and being free of mortal diseases is qualitatively superior to the pleasure of good quality sex (even if such good sex is guaranteed for an entire life) and thus the justification for the action does not stand. The concept of pleasure and pain and, therefore, happiness and 
suffering are totally objective when the other-regarding sphere is involved, when our actions directly affect other people without their consent.

However, and this is the important point, things change drastically in the self-regarding sphere, and they change for utilitarian reasons. Mill insists many times that each one of us is the most competent person to decide what our own well-being and pleasure is. He says that ${ }^{14}$ neither one person, nor any number of people is warranted in saying to another human adult that he shall not do with his life for his own benefit what he chooses to do with it. He is the person who is most interested in his own well-being. This is what Fuchs ${ }^{15}$ calls Mill's "epistemological argument" that individuals are generally themselves much better judges of what is most likely to please them and contribute to their well-being than others. The epistemological argument, I believe, has a very important role in a correct understanding of Mill's philosophy. In fact, if each of us knows better than anyone else about what brings us pleasure and pain, each of us knows better than anyone else what our happiness and our suffering consist of. This claim is not inconsistent with his previous claim in "Utilitarianism" that there are some kinds of pleasures that are more valuable than others, since in "On Liberty" he is just asserting that in the selfregarding sphere people should be free even to ignore the verdict of history and experience. In the other-regarding sphere the judgment of experience and accumulated knowledge through history has moral and legal force. In the self-regarding sphere the judgment of experienced people only has prudential value and the reason for this is precisely that, when all is said and done, each of us is a better judge than anyone else to decide what causes us pain and which kind of pleasure we prefer. According to Mill: ${ }^{16}$

Such are the differences among human beings in their source of pleasure, their susceptibilities of pain, and the operation on them of different physical and moral agencies, that unless there is a corresponding diversity in their modes of life, they neither obtain their fair share of happiness, nor grow up to the mental, moral, and aesthetic stature of which their nature is capable. Why then should tolerance, as far as the public sentiment is concerned, extend only to tastes and modes of life which extort acquiescence by the multitude of their adherents?

Then if in the self-regarding sphere people should be free to pursue their own happiness, even in ways that experience of humankind shows that it brings more pain than pleasure, we would have, curiously, in the long run, maximized 
happiness and minimized pain and each person would be allowed to have his/ her own good (each person's happiness is a good for that person) even if this good is not seen as a good by the rest of humankind. If the Greatest Happiness Principle is nothing but the aggregate of each person's happiness, leaving people free even to cause harm for themselves we still would be maximizing happiness, given the epistemological claim. If each of us knows better than anyone else what causes us pain and pleasure, what causes the happiness or suffering of the majority of people does not necessarily cause the happiness or suffering of a minority of individuals that, for whatever reason, does not have the same feelings of the majority. In other words, even though humankind has an objective criterion, an accumulated knowledge to decide what causes suffering and which pleasures are more valuable in society, society does not know what each individual feels like being painful or pleasurable. Thus, society cannot impose its views on individuals, forcing them to renounce their pleasures, on pain of not maximizing happiness, which would go against the Greatest Happiness Principle. This is the reason why Mill says: ${ }^{17}$

In the conduct of human beings towards one another, it is necessary that general rules should for the most part be observed, in order that people may know what they have to expect; but in each person's concern, his individual spontaneity is entitled to free exercise. Considerations to aid his judgement, exhortations to strengthen his will, may be offered to him, even obtruded on him, by others; but he himself is the final judge. All errors which he is likely to commit against advice and warning, are far outweighed by the evil of allowing others to constrain him to what they deem his good.

This reasoning is only complete, however, if it is understood that total freedom of action in the self-regarding sphere has another utility, i.e., it is an important way (together with freedom of opinion) of creating new paths for happiness through experiments in life, and thus it is important for the moral progress of humankind. And are precisely these experiments in the selfregarding sphere that will make room for the improvement of the judgment of the competent judges (each of us and humankind as a whole) bringing the moral development of humankind through history. Here, I interpret Mill as if he understands liberty in the self-regarding sphere as necessary for the maximization of happiness in the long term. In fact, if none of us ever experienced the low pleasures at some time in our lives, mankind would never be able to reach the state of having experienced people (the competent judges) 
because humankind would never learn from their mistakes. What I am actually saying here is that it is possible to conciliate the objective and the subjective criteria for, in the long run, the subjective criteria is one of the main conditions for the establishment of the objective criteria. It does not mean, however, that the objective criteria will never be applied. It will be applied, for example in the legal sphere, where the criteria to determine what is harmful, or not, to others should be totally objective (no one could say, for example, that they did not know that burning someone with a lit cigarette is painful and harmful). However, people should be free to act foolishly because, considering the history of the whole of mankind, past, present and future, happiness will still be maximized in the long term. Even if we objectively know that the life of a dissatisfied Socrates is better than the life of a satisfied fool, the satisfied fool contributes for the Greatest Happiness because, were it not for the foolish, we would never produce the experienced (the competent judges) people who know both sides, learning from the vast experience of others. So, even though the choices of the fool can be criticized (although never prohibited) using the objective criteria, the choices of a fool, will paradoxically maximize happiness in the long term, as the Greatest Happiness Principle is about the maximization of general happiness, and learning from the mistakes of some people will make the majority of people avoid making the same mistakes. Notice also that the subjective criteria does not put at stake Mill's distinction between qualitative and quantitative pleasures and objectively, pleasures of intellect, imagination and moral sentiments still have much higher value as pleasures than those of mere sensation, as Mill proposed..$^{18}$ It is just that in the self-regarding sphere people are completely free to subvert this order, if they wish, and taking into consideration the whole of mankind through history and time, these actions will still maximize happiness.

In a future ideal utilitarian state (whose idea in Mill is probably a mixture of Bentham's utilitarianism and some socialist ideas) ${ }^{19}$ each individual would have developed high tastes and faculties and thus would be able to feel pleasure in the most refined goods, including all kinds of so-called moral virtues. In order to achieve this ideal utilitarian state, ${ }^{20}$ laws, social arrangements and education should be used to establish, in the mind of the individual, an indissoluble

18 It could be rightly argued in order to show that the distinction between subjective/objective is not in contradiction with Mill's distinction of low and higher pleasures, that freedom of choice is probably included among the higher pleasures, but here, I have tried to show that the argument holds up even without this assumption.

19 See Mill (1967[1879]), pp 703-753.

20 Mill, 2001, p. 64. 
association between his own happiness and the good of the whole. On the other hand, as a second condition, in order for humankind to reach this ideal state one day, people should have complete liberty in the self-regarding sphere, even liberty to make mistakes and to do what humankind believes that would harm themselves, because this is one of the most efficient ways that each of us individually and humankind collectively has to learn, correct mistakes and to find new sources of pleasure, maximizing happiness. The suffering that could be created in this process would be always outweighed by the fact that a) people will have their pleasures and then what they believe is their happiness, and $b$ ) in the long run humankind would be better off with competent judges (each of us and our civilization as a whole) learning also through experience which kinds of pleasures are more pleasurable and which kinds of pains should be more avoidable. There are then utilitarian reasons, based on the Greatest Happiness Principle to admit that human freedom is a good. Liberty is then one of the main means to maximize happiness, even if, sometimes, by being free we can make ourselves suffer an avoidable suffering. ${ }^{21}$

We are now in a position to provide an answer to the objection that the Greatest Happiness Principle could be in contradiction with the Principle of Liberty in cases of self-harm, solving the "little toe" problem. In fact, even if we all know that it is foolish and stupid for people to cut off their own little toes without any foreseen benefit, causing unnecessary suffering for the perpetrator of the action, it actually does not breach the Utility Principle. If the epistemological argument is to be accepted, each of us is the final judge about what causes us suffering and pain, and it is always possible that for some reasons people who are cutting their toes think that they will be more acceptable to society, or that they will be more attractive (to facilitate the reasoning, imagine, for example, of body piercing) and that will give them considerable amount of pleasure. For them, the pleasure of being accepted by their group or being attractive overrides the pain of mutilation. We can always advise them and use our accumulated knowledge to show them that they are being silly, but all advice will always be prudential (it is stupid!), not moral (it is wrong!). If we apply the Greatest Happiness Principle to this question, it is impossible to conclude that less happiness is being produced in the world, since this is a typical self-regarding action, the person really believes that she/ he will be more happy without the toe and it is even possible, against all odds, that he/she really ends up being happier. 
Notice that the same conclusion might be reached using a more complex case such as the AIDS example. Let us suppose now that the partner that was infected knew that he/she would be infected and even so, voluntarily and fully informed, consented with the unsafe sex relationship because he/she also believed that the pleasure of a good quality sex for a long time outweighs the pain of a mortal illness. In this case, it is not society anymore that has to decide whether the action was harmful or not. Now, since the supposed victim has given his/her consent, we have a self-regarding action and the decision was based on what he/she feels is the most important kind of pleasure for her/ him. If the person believes that the pleasure of excellent, but unsafe, sex is more valuable than the pleasure of good health, again she/he is probably being extremely foolish, but not immoral. Additionally, supposing that this person will carry on private treatment, the Greatest Happiness Principle could not rule out the action, and we would have reached the same result obtained with the use of the Harm Principle, showing once more that there is no contradiction between the two principles and leaving us with the conclusion that Mill's philosophy is absolutely coherent, even though at the same time, it does not produce any conceptual apparatus for disallowing any kind of physical selfharm carried on voluntarily by adults.

\section{References}

DALTON, P. “The Irony of the Self-Harm Principle Pacific". Philosophical Quaterly, Vol. 63, pp. 381-391, 1982.

FEINBERG, J. "The Moral Limits of the Criminal Law: Harm to Others". Oxford: Oxford University Pres, 1984.

FUCHS, A. E. "Autonomy, Slavery and Mill's Critique of Paternalism". Ethical Theory and Moral Practice, Vol. 4, pp. 231-251, 2001.

GROARKE, L. "Paternalism and Egregious Harm: Prader-Willy Syndrome and The Importance of Care". Public Affairs Quaterly,Vol. 16, Nr. 3, pp. 203-227, Jul. 2002. LYONS, D. "Forms and Limits of Utilitarianism". Oxford: Oxford University Press, 1965.

MILL, J. S. "On Liberty". In: On Liberty and Other Essays. Ed. Stefan Collini. Cambridge: Cambridge University Press, 2000. . "Utilitarianism". Oxford: Oxford University Press, 2001.

"Chapters on Socialism". In: Mill's Collected Works. Ed. John Robson. Canada: University of Toronto Press, Routledge \&Kegan Paul, 1967[1879]. vol. V: Essays on Economic and Society, pp. 703-753. 